\title{
PRAWNA OCHRONA JEDNOSTKI PRZED NARUSZENIEM KONSTYTUCYJNEGO ZAKAZU DYSKRYMINACJI W RELACJACH HORYZONTALNYCH
}

\author{
LEGAL PROTECTION OF AN INDIVIDUAL AGAINST THE VIOLATION \\ OF THE CONSTITUTIONAL PROHIBITION OF DISCRIMINATION \\ IN HORIZONTAL RELATIONS
}

The purpose of this article is to discuss legal measures that allow an individual to seek protection against unequal or discriminatory treatment in horizontal relations. Taking as a starting point that Article 32(2) of the Constitution of the Republic of Poland and Article 33 of the Constitution are also applicable in horizontal relations, the author attempts to identify legal norms that protect an individual in this respect. In addition, an attempt is made at finding sanctions against violations of norms prohibiting discrimination. As part of the conducted deliberations, the author focuses on three basic legal acts, the civil code, the labor code, and the equality act, because they are the main normative source of protection of the individual against discrimination in horizontal relations. Individual legal institutions are discussed from the perspective of their scope of application in terms of subject and object and through the prism of potential sanctions. The author also undertakes an attempt to assess the effectiveness of these means and draws attention to the existing legislative shortcomings mainly related to the way of regulating the so-called actions against discrimination in the equality law. In the last part, the author makes considerations regarding the procedural aspects related to the pursuit of claims for discrimination, and in particular focuses on the institution's reversed burden of proof in this type of proceedings.

Słowa kluczowe: horyzontalny wymiar norm konstytucyjnych, prawo do równego traktowania, ochrona przed dyskryminacją, powództwo przeciw dyskryminacji, ustawa równościowa

Key words: horizontal dimension of constitutional norms, right to equal treatment, protection against discrimination, action against discrimination, equality law

* Mgr Pawel Śmiałek, Uniwersytet Warmińsko-Mazurski w Olsztynie, Katedra Prawa Konstytucyjnego, smialekolsztyn@gmail.com, https://orcid.org/0000-0001-6185-3451

\section{WSTĘP}

Z godnie z art. 32 ust. 1 Konstytucji RP wszyscy są wobec prawa równi, tzn. mają prawo do równego traktowania przez władze publiczne. Wyprowadza się stąd ogólną normę polegającą na tym, że podmioty znajdujące się w podobnej sytuacji powinny być traktowane w sposób podobny, a podmioty znajdujące się w sytuacji odmiennej — w sposób odmienny. W artykule tym chodzi więc o równe traktowanie podmiotów znajdujących się w tej samej sytuacji prawnej ${ }^{1}$. Z kolei art. 32 ust. 2 konstytucji stanowi, że nikt nie może być dyskryminowany w życiu politycznym, społecznym lub gospodarczym z jakiejkolwiek przyczyny. Trybunał Konstytucyjny przez dyskryminację rozumie ,zakaz nieuzasadnionego, różnego kształtowania

${ }^{1}$ Uchwała SN z 16 marca 2000 r., sygn. akt I KZP 56/99, OSKNW 2000, nr 3-4, poz. 19. 
sytuacji podobnych podmiotów prawa, w procesie stanowienia oraz stosowania prawa. Dyskryminacja oznacza zatem nienadające się do zaakceptowania tworzenie różnych norm prawnych dla podmiotów prawa, które powinny być zaliczone do tej samej klasy (kategorii), albo nierówne traktowanie podobnych podmiotów prawa w indywidualnych przypadkach, gdy zróżnicowanie nie znajduje podstaw w normach prawnych"2. W naukach społecznych, wskazuje się, że przyczyną sprawczą dyskryminacji są cechy osobowościowe człowieka³ . Określają one, jak podnosi się w nauce prawa, kim w sensie społecznym jest jednostka. Wyróżnia się podział cech osobowościowych człowieka na tożsamości pierwotne oraz wtórne. Do tożsamości pierwotnych zalicza się cechy wrodzone, które są niezależne od woli jednostki (wiek, płeć, orientacja psychoseksualna, pochodzenie etniczne i narodowe). Natomiast tożsamości wtórne to takie, na których zmianę mają wpływ działania jednostki, jak chociażby status jej rodziny lub też status ekonomiczny samej jednostki, wyznanie ${ }^{4}$. Mając na względzie, że cechy osobowości nie są zależne od woli jednostki, to brakuje aksjologicznego i prawnego uzasadnienia na ich podstawie do dokonywania zróżnicowania jednostki w sferze prawnej i społecznej. W rzeczywistości społeczno-prawnej dochodzi do nierównego traktowania podmiotów według jednej z opisanych cech, co nosi znamiona dyskryminacji.

Do pozytywnych obowiązków państwa należy zatem kreacja efektywnego i kompleksowego systemu ochrony jednostki przed dyskryminacją, także w stosunkach między podmiotami prawa prywatnego. Znajduje to uzasadnienia na podstawie wspomnianego już art. 32 ust. 2 konstytucji, mającego charakter stricte gwarancyjny. Celem niniejszego opracowania jest więc omówienie środków pozwalających jednostce na poszukiwanie ochrony prawnej w przypadku zaistnienia aktu dyskryminacji, ich podmiotowego i przedmiotowego zakresu oraz sposobu miarkowania ewentualnej rekompensaty.

\section{KONSTYTUCYJNE PRAWO DO RÓWNEGO TRAKTOWANIA I NIEDYSKRYMINACJI W WYMIARZE HORYZONTALNYM}

Konstytucyjny zakaz dyskryminacji jest kwalifikowaną postacią zasady równości, o której mowa w ust. 1 art. 32 konstytucji ${ }^{5}$, stanowi jej doprecyzowanie. Trybunał Konstytucyjny słusznie zauważył, że przepis art. 32 ust. 2 konstytucji jest uniwersalnym urzeczywistnieniem zasady równości, nakazując jej przestrzeganie we wszystkich sferach życia, a więc w życiu politycznym, społeczny i gospodarczym ${ }^{6}$. W literaturze podkreśla się, że katalog ten nie jest zamknięty ${ }^{7}$. Obejmuje zatem inne sfery życia, które

${ }^{2}$ Wyrok TK z 15 lipca 2010 r., sygn. akt K 63/07, OTK ZU/2010/6A/60.

${ }^{3} \mathrm{~W}$ naukach społecznych przez dyskryminację rozumie się niesprawiedliwe, krzywdzące, wybiórcze, niewłaściwe traktowanie osób ze względu na ich przynależność do pewnej społecznie rozpoznawalnej grupy, wyodrębnionej na podstawie jednej lub większej liczby cech tożsamości, np. kobiet (płeć), osób starszych (wiek) czy też muzułmanów (wyznanie). Jest ona zaprzeczeniem zasady równości. Stanowi naruszenie godności ludzkiej.

${ }^{4}$ A. Winiarska, W. Klaus, Dyskryminacja i nierówne traktowanie jako zjawisko spoteczno-kulturowe, „Studia BAS” 2011, nr 2, s. 9-40.

${ }^{5}$ Wyrok TK z 15 lipca 2007 r., sygn. akt K 63/07, OTK ZU/2010/6 A/60.

${ }^{6}$ Wyrok TK z 24 października 2001 r., sygn. akt K 22/01, OTK ZU/2001/7/216.

7 P. Winczorek, Komentarz do Konstytucji Rzeczypospolitej Polskiej, Warszawa 2008, s. 86. 
nie są wymienione przez ustrojodawcę, np. życie rodzinne lub osobiste. Jednak należy zauważyć, że rozważania te mają jedynie charakter teoretyczny. Przy szerokiej interpretacji zwrotu ,życie społeczne” niewiele relacji społecznych może znaleźć się w praktyce poza treścią tego przepisu' ${ }^{8}$.

Zakaz dyskryminacji obejmuje: po pierwsze - zakaz ustanawiania przez ustawodawcę regulacji pogarszających sytuację danej grupy podmiotów; po drugie zakaz inkorporowania regulacji poprawiających pozycję danej grupy podmiotów kosztem innych grup ${ }^{9}$; po trzecie — zakaz różnicowania sytuacji prawnej adresatów norm jedynie na podstawie indywidualnych cech osobowych ${ }^{10}$.

Ustrojodawca nie określił cech, które nie mogą stanowić podstawy różnicowania podmiotów prawa. W literaturze przedmiotu określa się je jako „cechy zakazane”"11. Konsekwencją przyjętego rozwiązania — jak słusznie zauważył Lech Garlicki — jest to, że dla konstytucyjnej dopuszczalności różnicowania pozycji podmiotów podobnych relewantne jest pytanie, czy różnicowanie to ma charakter uzasadniony, a nie pytanie, na podstawie jakich cech osobowościowych zostało dokonane. Dyskryminacja pojawia się wtedy, gdy stwierdzone zróżnicowanie podmiotów podobnych — co samo w sobie musi być klasyfikowane w kategoriach naruszenia zasady równości w świetle art. 32 ust. 1 konstytucji - oparto na cesze osobistej podmiotów różnicowanych, a nie znajduje to dostatecznego uzasadnienia ${ }^{12}$. Pewną wskazówką są także normy prawa międzynarodowego, którymi Polska jest związana ${ }^{13}$. Określają one expressis verbis cechy osobowościowe. Na szczególną uwagę zasługują przepisy art. 14 europejskiej Konwencji o ochronie prawa człowieka i podstawowych wolności ${ }^{14}$ oraz art. 26 Międzynarodowego Paktu Praw Obywatelskich i Politycznych ${ }^{15}$.

${ }^{8}$ Tak też, B. Banaszak, uwagi do art. 32 Konstytucji, [w:] Konstytucja RP. Komentarz, Warszawa 2012.

9 Vide uzasadnienie do wyroku TK z 9 marca 1988 r., sygn. akt U 8/87, OTK ZU/1988/1/1.

10 Vide wyrok TK z 5 lipca 2011, sygn. akt P 14/10, OTK ZU/2011/6A/49.

${ }^{11}$ L. Bosek, W. Borysiak, uwagi do art. 32 Konstytucji RP, [w:] Konstytucja RP. Komentarz, red. M. Safjan, L. Bosek, t. I, Warszawa 2016, s. 839.

${ }^{12}$ L. Garlicki, M. Zubik, uwagi do art. 32, [w:] Konstytucja Rzeczypospolitej Polskiej. Komentarz, red. L. Garlicki, M. Zubik, t. II, Warszawa 2016.

${ }_{13}$ M. Masternak-Kubiak, Prawo do równego traktowania, [w:] Prawa i wolności obywatelskie w Konstytucji RP, red. B. Banaszak, A. Preisner, Warszawa 2002, s. 128-129.

${ }^{14}$ Konwencja o ochronie praw człowieka i podstawowych wolności sporządzona z 4 listopada 1950 r., zmieniona Protokołami nr 3, 5 i 8 oraz uzupełniona Protokołem nr 2 (Dz.U. z 1993 r. nr 6, poz. 284). Zgodnie z jej art. 14: „Korzystanie z praw i wolności wymienionych w niniejszej konwencji powinno być zapewnione bez dyskryminacji wynikającej z takich powodów, jak płeć, rasa, kolor skóry, język, religia, przekonania polityczne i inne, pochodzenie narodowe lub społeczne, przynależność do mniejszości narodowej, majątek, urodzenie bądź z jakichkolwiek innych przyczyn”.

${ }_{15}$ Międzynarodowy Pakt Praw Obywatelskich i Politycznych z 19 grudnia 1966 r. (Dz.U. z 1977 r. nr 38, poz. 167). Zgodnie z art. 26: „Wszyscy są równi wobec prawa i są uprawnieni bez żadnej dyskryminacji do jednakowej ochrony prawnej. Jakakolwiek dyskryminacja w tym zakresie powinna być ustawowo zakazana oraz powinna być zagwarantowana przez ustawę równa dla wszystkich i skuteczna ochrona przed dyskryminacją z takich względów, jak: rasa, kolor skóry, płeć, język, religia, poglądy polityczne lub inne, pochodzenie narodowe lub społeczne, sytuacja majątkowa, urodzenie lub jakiekolwiek inne okoliczności”. 
Konstytucyjną ochroną przed dyskryminacją objęte są wszystkie podmioty. Do takich wniosków prowadzi literalna wykładnia omawianego przepisu, albowiem ustrojodawca użył zwrotu „nikt”. Trybunał podkreślił, że prawo równości i niedyskryminacji odnosi się do wszystkich osób podlegających jurysdykcji Rzeczypospolitej Polskiej ${ }^{16}$ i ma zastosowanie do osób fizycznych, osób prawnych, a także wszelkich innych podmiotów konstytucyjnych praw i wolności, bez względu na ich narodowość ${ }^{17}$.

Ustalając treść konstytucyjnego zakazu dyskryminacji, należy określić podmioty zobowiązane do jego przestrzegania, a ponadto odpowiedzieć na pytanie, czy ten konstytucyjny zakaz jest aktualny wyłącznie w stosunkach wertykalnych, czy także w horyzontalnych. W celu przejścia do szczegółowych rozważań, zdefiniowania wymagają pojęcia „wertykalnego” i „horyzontalnego” działania praw konstytucyjnych. Kategoryzowanie obu relacji jest determinowane nawiązaniem w pierwszej kolejności stosunku prawnego, rozumianego sensu largo. Sławomira Wronkowska zdefiniowała stosunek prawny jako ,społeczny stosunek tetyczny wyznaczony przez normę prawną i powstający między co najmniej dwoma podmiotami prawnymi. Polegający na tym, że dana norma prawna wyznacza jakiemuś podmiotowi określone zachowania odnoszące się do innej osoby, czy też spraw tej osoby"18. Każdy stosunek prawny zawiera szereg konstytutywnych elementów, tj. podmiot, przedmiot, uprawnienia oraz obowiązki ${ }^{19}$. Dopiero powstanie stosunku prawnego pozwala na dalszą analizę prowadzącą do określania jego charakteru. Wertykalny stosunek prawny zawiązuje się ze względu na określoną normę kompetencyjną wskazaną w akcie prawnym, która wyznacza jej adresatowi obowiązek zrealizowania określonego zachowania w sytuacji, gdy organ uzyskujący kompetencje uczyni z niej użytek i dokona stosowną czynność konwencjonalną, do której został upoważniony ${ }^{20}$. Oznacza to, że organ działa na podstawie zasady legalizmu i nie ma prawa wykroczyć poza uprawnienia kompetencyjne. Występowanie elementu władztwa jest charakterystyczne dla stosunków administracyjnoprawnych, w których jeden z podmiotów zajmuje pozycję nadrzędną i może w sposób władczy wpływać na pozycję prawną innego podmiotu (innych podmiotów), np. nakładając na nie obowiązki ${ }^{21}$.

16 Vide wyrok TK z 24 lutego 1999 r., sygn. akt SK 4/98, OTK ZU 1999/2/24.

17 Vide wyrok TK z 18 kwietnia 2000 r., sygn. akt K 23/99, OTK ZU 2000/3/89.

18 S. Wronkowska, Z. Ziembiński, Zarys teorii prawa, Poznań 2001, s. 115.

19 Podmiotami stosunków cywilnoprawnych mogą być osoby fizyczne, osoby prawne oraz w określonych sytuacjach jednostki organizacyjne nieposiadające osobowości prawnej. Za przedmiot stosunku cywilnoprawnego należy uznać zarówno zachowania ludzi, jak i te obiekty, których dane zachowanie dotyczy. Natomiast wynikające ze stosunku prawnego uprawnienia i obowiązki w doktrynie określane są jako jego treść. Uprawnieniem jednej strony (tzn. określonemu w dyspozycji normy prawnej zakresowi tego, co jej czynić wolno) odpowiada obowiązek drugiej strony polegający na tym, że osoba ta powinna zachować się w oznaczony w tejże dyspozycji sposób. Kategorią wyższego rzędu względem uprawnień, za pomocą którego określa się w prawie cywilnym sytuację podmiotu uprawnionego, złożoną przeważnie z kilkunastu powiązanych ze sobą uprawnień „cząstkowych”, jest prawo podmiotowe.

20 S. Wronkowska, Z. Ziembiński, Zarys teorii prawa..., s. 115.

21 Wyrok WSA w Warszawie z 11 maja 2005 r., sygn. akt III SA/Wa 126/05, Lex nr 230841. 
Natomiast nawiązanie stosunku horyzontalnego jest związane z równorzędnością stron, rozumianą jako brak podporządkowania, czyli możliwości władczego kształtowania sytuacji prawnej innego podmiotu na mocy określonej normy kompetencyjnej. Oprócz równorzędności stron charakterystyczna jest również autonomia stron, która przejawia się w swobodzie podejmowania decyzji o dokonaniu czynności prawnej, wyborze drugiej strony i kształtowaniu treści powstającego stosunku prawnego. Równorzędność stron jest typowa dla prawa prywatnego. Charakterystyczną cechą wskazanej dziedziny prawa jest przyznanie podmiotom prawa swobody samodzielnego decydowania o swoich celach i sposobach ich realizacji. Podstawowym aspektem i przejawem autonomii podmiotów prawa prywatnego jest zasada swobody umów ${ }^{22}$.

W doktrynie i orzecznictwie nie budzi zastrzeżeń zastosowanie konstytucyjnego prawa do równego traktowania i niedyskryminacji w stosunkach wertykalnych ${ }^{23}$. Kontrowersje budzi natomiast jego horyzontalna implikacja. Część przedstawicieli nauki podnosi, że konstytucyjne prawo do równego traktowania i niedyskryminacji nie ma zastosowania w stosunkach horyzontalnych ${ }^{24}$. Wskazują oni, że za taką interpretacją przemawia literalna wykładnia art. 32 ust. 1 konstytucji. Obowiązek równego traktowania i niedyskryminacji nie może bowiem spoczywać na podmiotach niepublicznych ${ }^{25}$. Wydaje się jednak, że analogiczne tezy nie mogą być wysunięte wobec art. 32 ust. 2 i art. 33 konstytucji.

Przepis art. 32 ust. 1 konstytucji w istocie zawiera zwrot, ,wszyscy mają prawo do równego traktowania przez władze publiczne", co prowadzi do uznania, że jest on adresowany do władz publicznych. Należy jednak podkreślić, że ustrojodawca nie wskazał „władz publicznych” w ust. 2 tejże normy. Co więcej, odwołał się do życia politycznego, społecznego i gospodarczego, a więc sfer obejmujących życie jednostki nie tylko w stosunkach wertykalnych, ale przede wszystkim horyzontalnych. Pojęcia ,życia” jest bowiem w ujęciu semantycznym zwrotem szerokim. Wynik wykładni językowej prowadzi do wniosku o rozszerzonym zakresie normowania art. 32 ust. 2 konstytucji. Postawiona teza znajduje także potwierdzenie w wykładni funkcjonalnej i celowościowej. Ustawa zasadnicza jest bowiem odzwierciedleniem pożądanych w społeczeństwie wartości. Niewątpliwie do takich należy zaliczyć godność człowieka, prawo do poszanowania czci, dobrego imienia, prywatności czy też wolności wyznania i sumienia. Wszelkie te wartości mogą zostać naruszone w przypadku dyskryminacji w stosunkach horyzontalnych. Niewskazanie władz publicznych w art. 32 ust. 2 konstytucji, a także szerokie określenie sfer funkcjonowania jednostki prowadzi do konstatacji, że przepis ten może znaleźć zastosowanie w stosunkach horyzontalnych. Do analogicznych wniosków prowadzi analiza treści art. 33

22 P. Sobolewski, uwagi do art. 1 k.c., [w:] Kodeks cywilny. Komentarz, t. I, red. K. Osajda, Warszawa 2018.

${ }^{23}$ Vide L. Bosek, W. Borysiak, Konstytucja..., s. 839; tak też wyrok TK z 24 października 2001 r., sygn. akt SK 22/01, OTK 2001/7/216.

${ }^{24}$ L. Bosek, W. Borysiak, Konstytucja..., s. 839.

25 Ibidem. 
konstytucji ${ }^{26}$. Ustrojodawca w ramach rzeczonej normy wyraźnie nie egzemplifikuje podmiotu zobowiązanego jej treścią. Ponadto w obu ustępach wymienia obszary charakterystyczne dla stosunków horyzontalnych, takie jak m.in. życie rodzinne lub społeczne (ust. 1) oraz prawo do równego traktowania w zatrudnieniu, awansach i wynagrodzeniu (ust. 2). Jak trafnie zauważyli Leszek Garlicki i Marek Zubik, zawarte $\mathrm{w}$ art. 33 konstytucji wyliczenie jest szersze niż to zawarte w art. 32 ust. 2 (bo obejmuje dodatkowo sferę życia rodzinnego). Ma ono charakter uniwersalny. Obejmuje właściwie wszystkie sfery, w których prawo wyznacza pozycję obu płci, dlatego też można mówić o horyzontalnym wymiarze tego przepisu ${ }^{27}$.

Nie sposób także pominąć doniosłości art. 8 ust. 2 konstytucji ${ }^{28}$. Skoro bowiem ustrojodawca dopuszcza możliwość bezpośredniego stosowania przepisów ustawy zasadniczej, to także powinna być ona przestrzegana w stosunkach między pomiotami znajdującymi się poza systemem władzy publicznej. W ustawie zasadniczej znajdują się normy prawne, które wprost wskazują na swój horyzontalny skutek (zakaz wyzysku, zakaz pracy małoletnich). Z kolei art. 31 ust. 2 konstytucji zobowiązuje „każdego" do poszanowania praw i wolności innych.

W doktrynie wyróżnia się trzy sposoby stosowania norm konstytucyjnych ${ }^{29}$. Pierwszym z nich jest samoistne stosowanie przepisów konstytucji polegające na tym, że organ władzy publicznej opiera swe rozstrzygnięcie jedynie na przepisie konstytucji. W ten sposób ustawę zasadniczą stosuje TK. Może być ona realizowana przez organy naczelne państwa. Wyjątkowo samoistnie sądy mogą stosować konstytucję ${ }^{30}$. Drugim sposobem jest współstosowanie konstytucji i innych aktów normatywnych, zwłaszcza ustaw. Polega ono na dokonywaniu wykładni ustaw w zgodzie z konstytucją. W wersji ekstensywnej polega na odrzuceniu rezultatu wykładni ustawy, który jest niezgodny z konstytucją. W wersji intensywnej skupia się na wyborze rezultatu wykładni przepisów ustawy, który w największym stopniu pozostaje w zgodzie z konstytucją. Współstosowanie konstytucji i ustaw zwykłych najczęściej występuje w sądowym stosowaniu prawa. Trzecim sposobem stosowania norm konstytucyjnych jest

${ }^{26}$ Zgodnie z art. 33 ust. 1 i 2 konstytucji: „1. Kobieta i mężczyzna w Rzeczypospolitej Polskiej mają równe prawa w życiu rodzinnym, politycznym, społecznym i gospodarczym; 2. Kobieta i mężczyzna mają w szczególności równe prawo do kształcenia, zatrudnienia i awansów, do jednakowego wynagradzania za pracę jednakowej wartości, do zabezpieczenia społecznego oraz do zajmowania stanowisk, pełnienia funkcji oraz uzyskiwania godności publicznych i odznaczeń".

27 L. Garlicki, M. Zubik, uwagi do art. 33 konstytucji, [w:] Konstytucja Rzeczypospolitej Polskiej. Komentarz, t. II, red. L. Garlicki, M. Zubik, Warszawa 2016.

${ }^{28}$ Zgodnie z art. 8 ust. 2 konstytucji: „Przepisy Konstytucji stosuje się bezpośrednio, chyba że Konstytucja stanowi inaczej".

${ }_{29}$ Vide P. Tuleja, Stosowanie Konstytucji RP w świetle zasady jej nadrzędności (wybrane problemy), Kraków 2003, s. 369.

${ }^{30} \mathrm{~W}$ odniesieniu do samoistnego stosowania przepisów Konstytucji RP decyduje stopień konkretyzacji przepisów. Norma konstytucyjna może stanowić podstawę prawną, jeżeli jest skonkretyzowana w stopniu pozwalającym na samoistne jej zastosowanie. Vide wyrok SN z 8 stycznia 2009 r., sygn. akt I CSK 482/08, „Biuletyn Sądu Najwyższego” 2009, nr 6; podobnie wyrok SA w Warszawie z 10 maja 2013 r., sygn. akt VI ACa 1362/12, Legalis. 
stwierdzenie konfliktu norm konstytucji i innych aktów normatywnych. Ta forma bezpośredniego stosowania konstytucji wiąże się z dyskusją o dopuszczalności odmowy zastosowania niekonstytucyjnego przepisu ustawy przez sąd ${ }^{31}$.

Przenosząc powyższe rozważania na zastosowanie art. 32 ust. 2 i art. 33 konstytucji, należy podkreślić, że najczęściej będą one współstosowane z przepisami ustaw zwykłych. Przepisy te wyrażają niezwykle ważną wartość społeczną, zgodnie z którą nikt nie powinien być dyskryminowany ze względu na cechy osobowościowe (niezależne od swojej woli). Każdemu z tego tytułu powinna przysługiwać pełniejsza ochrona prawna. Tylko wówczas możliwe będzie pełne urzeczywistnienie ochrony przed dyskryminacją w stosunkach prywatnych. Odmienna wykładnia spowodowałaby, że konstytucyjna ochrona przed dyskryminacją obejmie swym zakresem wyłącznie stosunki wertykalne. Stanowiłoby to przyczynek do narażenia jednostki na dyskryminację w stosunkach horyzontalnych, stanowiących przecież niezwykle istotną część funkcjonowania jednostki w społeczeństwie. Konstytucyjna aksjologia w praktyce stałaby się fikcyjna. Prawo do niedyskryminacji powinno mieć zastosowanie uniwersalne. Nie sposób pominąć stanowisko TK opowiadającego się za wykładnią prohoryzontalną — tego typu interpretacji Trybunał dokonał w orzeczeniu z 13 kwietnia 2000 r. $^{32}$ dotyczącego pracodawców ${ }^{33}$. W uzasadnieniu TK konstatował, że należy przyjąć za dopuszczalne zobowiązanie podmiotów innych niż publiczne do przestrzegania zasady równouprawnienia kobiet i mężczyzn. Niniejszy wniosek należy uznać za zasadny.

Ponownego podkreślenia wymaga, że przedstawiona wykładnia jest przyczynkiem ku zwiększeniu ochrony jednostek przed dyskryminacją w stosunkach horyzontalnych. W obecnych realiach społeczno-gospodarczych istnieje wysokie zagrożenie wystąpieniem przejawów dyskryminacji w stosunkach prywatnych, zwłaszcza gdy podmioty w rzeczywistości nie są równorzędne, choć w rozumieniu prawnym taka relacja powinna zachodzić. Klasycznym przykładem jest relacja pracownik i pracodawca oparta na zasadzie równości, choć przy faktycznej dominacji pracodawcy

${ }^{31}$ Omówienie tego aspektu bezpośredniego stosowania konstytucji wykracza poza ramy przedmiotowego opracowania. Vide szerzej L. Garlicki, Bezpośrednie stosowanie Konstytucji, [w:] Konstytucja RP w praktyce. Konferencja naukowa, Warszawa 1999. Należy zauważyć, że przedstawiciele doktryny w tym przedmiocie nie są zgodni, albowiem część z nich dopuszcza możliwość odmowy zastosowania niekonstytucyjnego przepisu ustawy przez sąd (vide W. Sanetra, Bezpośrednie stosowanie Konstytucji przez Sąd Najwyższy, [w:] Bezpośrednie stosowanie Konstytucji Rzeczypospolitej Polskiej. Bezpośrednie stosowanie Konstytucji RP przez Trybunat Konstytucyjny, red. K. Działocha, Warszawa 2005, s. 49).

32 Wyrok TK z 13 czerwca 2000 r., sygn. akt K 15/99, OTK 2000/5/13.

${ }^{33}$ Niniejsza sprawa dotyczyła szczególnego uprawnienia przyznanego przez ustawodawcę kobietom, w tym pełniącym funkcję kierowników aptek, tzn. prawa do wcześniejszego, w stosunku do mężczyzn, uzyskania świadczeń emerytalnych. Wnioskodawca w przedmiotowej sprawie zaskarżył art. 40 ust. 1 ustawy farmaceutycznej w zakresie, w jakim uniemożliwiała ona zajmowanie stanowiska kierownika apteki kobiecie, która nie osiągnęła wieku emerytalnego ustalonego dla mężczyzn jako niezgodny z art. 33 ust. 2 i art. 65 ust. 1 konstytucji oraz z art. 11 konwencji antydyskryminacyjnej. Wskazane wzorce obejmują konstytucyjne zasady równości kobiet i mężczyzn w zakresie zatrudnienia i zajmowania stanowisk, oraz swobody wyboru i wykonywania zawodu, a także konwencyjną regułę dążenia do likwidacji wszelkich przejawów dyskryminacji kobiet w dziedzinie zatrudnienia. 
w sytuacji zwiększonego popytu na pracę. Ponadto coraz częściej podmioty prywatne wykonują zadania klasycznie uznawane za wykonywane przez podmioty publiczne. Prywatyzacja zadań publicznych jest szczególnie zauważalna w takich dziedzinach jak oświata i służba zdrowia ${ }^{34}$. $Z$ tej perspektywy konieczne staje się urzeczywistnienie zasady niedyskryminacji $\mathrm{w}$ stosunkach prywatnych. Zaproponowana wykładnia konstytucyjnej zasady niedyskryminacji i równego traktowania pozostaje również w zgodzie z prawem stanowionym przez UE. W licznie transponowanych do prawa polskiego dyrektyw unijnych podkreśla się konieczność przestrzegania zakazu dyskryminacji w stosunkach społeczno-gospodarczych, podlegających regulacji prawu prywatnemu ${ }^{35}$. Możliwość horyzontalnego oddziaływania zasady niedyskryminacji podkreśla także część przedstawicieli doktryny prawa konstytucyjnego ${ }^{36}$, wskazując przy tym na wyżej przytoczoną argumentację.

Przyjęcie dopuszczalności zastosowania art. 32 ust. 2 i art. 33 konstytucji w stosunkach horyzontalnych nie zmienia faktu, że przepisy te należy stosować z daleko idącą ostrożnością. Zauważalny jest bowiem często konflikt między prawem do równego traktowania a wolnością drugiej jednostki. Konieczne jest każdorazowe odniesienie do okoliczności konkretnej sprawy. W szczególności nie jest możliwe w przypadku zakazu dyskryminacji aprioryczne przyjęcie warunków skuteczności tych przepisów w stosunkach horyzontalnych. Sądy bowiem stają przed trudnym zadaniem wyważenia z jednej strony potrzeby ochrony konstytucyjnych praw i wolności człowieka, a z drugiej - autonomii jednostki. Uwagę zwraca jednak fakt, że sądy powszechne oraz Sąd Najwyższy wyrażają gotowość współstosowania art. 32 ust. 2 i art. 33 konstytucji w stosunkach horyzontalnych, odwołując się często do istoty tych przepisów w uzasadnieniach orzeczen ${ }^{37}$.

${ }^{34}$ Vide C. Włodarczyk, Wokót prywatyzacji w ochronie zdrowia. Kilka Problemów, Biblioteka Cyfrowa, <http://www.problemypolitykispolecznej.pl/images/czasopisma/13-14/13-14_18-41.pdf>, dostęp 20 IV 2018.

${ }^{35}$ Dyrektywa Rady 2004/113/WE z 13 grudnia 2004 r. wprowadzająca w życie zasadę równego traktowania mężczyzn i kobiet w zakresie dostępu do towarów i usług oraz dostarczania towarów i usług (Dz.Urz. UE L 373 z 21.12.2004, s. 37); dyrektywa 2006/54/WE Parlamentu Europejskiego i Rady z 5 lipca 2006 r. w sprawie wprowadzenia w życie zasady równości szans oraz równego traktowania kobiet i mężczyzn w dziedzinie zatrudnienia i pracy (Dz. Urz. UE L 204 z 26.07.2006, s. 23), podsumowująca przepisy wydawanych od lat siedemdziesiątych XX w. dyrektyw mających na celu zagwarantowanie przestrzegania zasady równości kobiet i mężczyzn. Dyrektywa 2000/78/WE odnosząca się do zakazu dyskryminacji ze względu na religię, przekonania, wiek, niepełnosprawność oraz orientację seksualną (Dz. Urz. UE L 303 z 2.08.2000, s. 16-22); dyrektywa Rady 2000/43/WE z 29 czerwca 2000 r. wprowadzająca w życie zasadę równego traktowania bez względu na pochodzenie rasowe lub etniczne (Dz. Urz. UE L 180 z 19.07.2000, s. 22); dyrektywa Parlamentu Europejskiego i Rady z 16 kwietnia 2014 r. w sprawie środków ułatwiających korzystanie z praw przyznanych pracownikom w kontekście swobodnego przepływu pracowników (Dz. Urz. UE L 128 z 30.04.2014, s. 8).

${ }^{36}$ Vide M. Masternak-Kubiak, Prawo do... s. 136; P. Winczorek, Komentarz..., s. 87; M. Florczak-Wątor, Horyzontalny wymiar praw konstytucyjnych, Kraków 2014.

37 Vide wyrok SO w Olsztynie z 15 listopada 2017 r., sygn. akt IX Ca 625/17; wyroki SN z 18 stycznia 2007 r., sygn. akt I CSK 376/06, OSP 2008, z. 4, poz. 44 i z 18 stycznia 2007 r., sygn. akt I CSK 351/06, niepubl.; wyrok SA w Szczecinie z 10 kwietnia 2014 r., sygn. akt I ACa 731/13. 


\section{III. ŚRODKI PRAWNE IMPLEMENTUJĄCE OCHRONE PRAWNĄ PRZED DYSKRYMINACJĄ}

Przyjęcie, że konstytucyjne prawo do niedyskryminacji ma wymiar horyzontalny, pozwala na rozważenie, jakie środki prawne przysługują podmiotom prawa w przypadku jej naruszenia. Jak zostało już podkreślone, przepisy art. 32 i 33 konstytucji — co do zasady — nie znajdą zastosowania jako samoistne podstawy prawne przy dochodzeniu roszczeń przez ofiarę dyskryminacji. Możliwe jest jednak ich pośrednie stosowanie, co skutkuje koniecznością powołania normy prawnej ustanowionej na poziomie ustawy zwykłej. Rzeczony przepis zawiera normę sankcjonowaną, nie zawiera jednak normy sankcjonującej. Powoduje to konieczność odwołania się do norm rangi ustawowej, bowiem zostały one ustanowione na tym właśnie poziomie.

Należy wyróżnić trzy główne podstawy prawne pozwalające na dochodzenie roszczeń w związku z dyskryminacją ${ }^{38}$. Podstawowym środkiem ochrony będzie powództwo oparte na przepisach kodeksu cywilnego [dalej: k.c. ${ }^{39}$, czyli art. 23 k.c. ${ }^{40}$ i 24 k.c. ${ }^{41}$. Drugim środkiem prawnym będzie powództwo oparte na podstawie przepisów kodeksu pracy [dalej: k.p.] $]^{42}$, w szczególności art. $18^{43}$. Ostatnim zaś powództwo przeciw dyskryminacji oparte na art. 13 ust. $1^{44}$ ustawy o wdrożeniu niektórych przepisów w zakresie równego traktowania [dalej: ustawa równościowa lub u.o.r.] ${ }^{45}$. Różnorodność

${ }^{38}$ Poza wskazanymi instrumentami prawnymi w systemie prawnym istnieją odrębne środki zapewniające niemajątkową ochronę przed dyskryminacją, np. możliwość wytoczenia powództwa o uchylenie uchwały wspólnoty mieszkaniowej, jeżeli ta jest niezgodna z przepisami prawa na podstawie art. 25 ust. 1 ustawy z dnia 24 czerwca 1994 r. o własności lokali (Dz.U. z 2018 r. poz. 716), możliwość odwołania się od decyzji administracyjnych wydawanych na podstawie ustawy z dnia 27 lipca 2005 r. o szkolnictwie wyższym (Dz.U. z 2017 r. poz. 2183) na podstawie art. 169 ust. 12. Na podstawie ustawy z dnia 25 lutego 1964 r. - Kodeks rodzinny i opiekuńczy (Dz.U. z 2017 r. poz. 682) odnajdziemy regulacje, które chronią dziecko przed dyskryminacyjnym traktowaniem przez jednego z rodziców (vide art. 98 § 2 k.r.i.o).

${ }^{39}$ Ustawa z dnia 23 kwietnia 1964 r. — Kodeks cywilny (Dz.U. z 2018 r. poz. 1025).

${ }^{40}$ Zgodnie z art. 23 k.c.: „Dobra osobiste człowieka, jak w szczególności zdrowie, wolność, cześć, swoboda sumienia, nazwisko lub pseudonim, wizerunek, tajemnica korespondencji, nietykalność mieszkania, twórczość naukowa, artystyczna, wynalazcza i racjonalizatorska, pozostają pod ochroną prawa cywilnego niezależnie od ochrony przewidzianej w innych przepisach".

${ }^{41}$ Zgodnie z art. 24 § 1 i 2 k.c.: „§ 1 . Ten, czyje dobro osobiste zostaje zagrożone cudzym działaniem, może żądać zaniechania tego działania, chyba że nie jest ono bezprawne. W razie dokonanego naruszenia może on także żądać, ażeby osoba, która dopuściła się naruszenia, dopełniła czynności potrzebnych do usunięcia jego skutków, w szczególności, ażeby złożyła oświadczenie odpowiedniej treści i w odpowiedniej formie. Na zasadach przewidzianych w kodeksie może on również żądać zadośćuczynienia pieniężnego lub zapłaty odpowiedniej sumy pieniężnej na wskazany cel społeczny. §2. Jeżeli wskutek naruszenia dobra osobistego została wyrządzona szkoda majątkowa, poszkodowany może żądać jej naprawienia na zasadach ogólnych".

${ }^{42}$ Ustawa z dnia 26 czerwca 1974 r. - Kodeks pracy (Dz.U. z 2018 r. poz. 108).

${ }^{43}$ Zgodnie $\mathrm{z}$ art. $18^{3 \mathrm{~d}}$ k.p.: „Osoba, wobec której pracodawca naruszył zasadę równego traktowania w zatrudnieniu, ma prawo do odszkodowania w wysokości nie niższej niż minimalne wynagrodzenie za pracę, ustalane na podstawie odrębnych przepisów”.

${ }^{44}$ Zgodnie z art. 13 ust. 1 ustawy równościowej: „Każdy, wobec kogo zasada równego traktowania została naruszona, ma prawo do odszkodowania".

${ }^{45}$ Ustawa z dnia 3 grudnia 2010 r. o wdrożeniu niektórych przepisów Unii Europejskiej w zakresie równego traktowania (Dz.U. z 2016 r. poz. 1219). 
wymienionych środków prawnych powoduje konieczność ich dyferencjacji. Nie mogą one bowiem wspólnie stanowić podstawy dochodzonych roszczeń. Mają odmienny przedmiotowy i podmiotowy zakres stosowania.

Niewątpliwie najszerszy zakres zastosowania będzie miał art. 23 k.c., który zapewnia ochronę dóbr osobistych, rozumianych jako indywidualne wartości świata uczuć oraz stanu psychicznego człowieka ${ }^{46}$, będących wyrazem odrębności fizycznej lub psychicznej jednostki, powszechnie akceptowanych w społeczeństwie ${ }^{47}$. Dobra osobiste mają charakter przyrodzony i przysługują na równi wszystkim ludziom bez względu na ich cechy osobiste. Zakres przedmiotowy będzie natomiast obejmować wszelkie sytuacje, w których doszło do naruszenia dóbr osobistych, także związanych z aktami dyskryminacji. $\mathrm{W}$ istocie ustawodawca $\mathrm{w}$ treści przepisu literalnie nie wskazał ochrony przed dyskryminacją. Wymienił jednak dobra osobiste, których naruszenie jest ściśle związane z dyskryminacją. Eksplikowane zostały m.in. cześć, swoboda sumienia, nazwisko, wizerunek. Katalog ten jest otwarty. W judykaturze wyróżnia się też inne dobra osobiste ${ }^{48}$. Na szczególną uwagę zasługuje godność człowieka. W konstytucji godności nadano nadrzędne znaczenie, wskazując ją jako źródło wszystkich wolności i praw oraz podkreślając jej nienaruszalny charakter. TK również zaznaczył szczególną pozycję godności człowieka w ochronie dóbr osobistych jednostki. Uznał, że dobra osobiste człowieka, w szczególności dobre imię, cześć i prywatność, stanowią kwintesencję oraz emanację godności ${ }^{49}$. Trybunał trafnie przyjął, że prawa i wolności związane silniej z godnością człowieka powinny być szerzej chronione, pozostałe dobra osobiste oraz system ich ochrony stanowią jej emanację. Brak cywilnoprawnej ochrony godności człowieka stanowiłby naruszenie art. 30 konstytucji ${ }^{50}$. Nie każde naruszenie dóbr osobistych będzie związane z naruszeniem godności człowieka, jednak akty dyskryminacji wiążą się zwykle z naruszeniem tej sfery ${ }^{51}$. Otwarcie katalogu dóbr osobistych także na godność człowieka jest przykładem pośredniego oddziaływania konstytucji na stosunki cywilnoprawne (horyzontalne) i nakłada na podmioty prawa prywatnego obowiązek poszanowania godności drugiej strony, a więc także nakaz jej niedyskryminacyjnego traktowania.

Cywilistyczna koncepcja dóbr osobistych stanowi wyraz ochrony wartości uczuć oraz stanu psychicznego jednostki za pomocą instrumentów cywilnoprawnych, w szczegól-

${ }^{46}$ S. Grzybowski, Ochrona dóbr osobistych wedhug przepisów ogólnych prawa cywilnego...

${ }^{47}$ Wyrok SN z 6 maja 2010 r., sygn. akt II CSK 640/09, Legalis.

${ }^{48}$ P. Sobolewski, uwagi do art. 23 k.c., [w:] Kodeks cywilny. Komentarz...

${ }^{49}$ Wyrok TK z 30 października 2006 r., sygn. akt P 10/06, OTK 2006/9A/128.

${ }^{50}$ Ibidem.

${ }^{51}$ Słusznie na ten aspekt zwrócił uwagę SA w Poznaniu, orzekając w przedmiocie odmowy wejścia przedstawicielowi społeczności romskiej do klubu rozrywkowego tylko ze względu na jego pochodzenie etniczne. W uzasadnieniu do wyroku Sąd zajął stanowisko, że z naruszeniem godności mamy do czynienia, jeśli działanie albo zaniechanie stanowiące naruszenie innego dobra osobistego następuje w sposób godzący w wartość jednostki ludzkiej. Naruszeniem godności jest np. dyskryminacja jednostki ze względu na pochodzenie etniczne (vide wyrok SA w Poznaniu z 29 lutego 2012 r., sygn. akt I ACa 1162/11, Legalis). 
ności osobistych praw podmiotowych. Prawo do równego (niedyskryminacyjnego) traktowania należy uznać za prawo podmiotowe jednostki, podlegające ochronie nie tylko w stosunkach z władzami publicznymi, ale także w stosunkach horyzontalnych.

Dobra osobiste mają postać praw podmiotowych bezwzględnych (skutecznych wobec wszystkich) i niezbywalnych (ściśle związanych z podmiotem) ${ }^{52}$. Mają charakter niemajątkowy. Nie oznacza to jednak, że konsekwencje ich naruszenia nie mogą mieć charakteru majątkowego. Podmiot dotknięty dyskryminacją może nie tylko dochodzić roszczeń wskazanych w art. 24 k.c. ${ }^{53}$, ale także wynikających z art. 448 k.c. ${ }^{54}$. Jest to słuszne rozwiązanie, bowiem ze zjawiskiem dyskryminacji najczęściej jest związana nie tylko szkoda materialna, ale przede wszystkim krzywda niemajątkowa. Powstająca w wyniku wewnętrznego urazu psychicznego wymagającego stosownego zadośćuczynienia. Problematyczną materią pozostaje miarkowanie rekompensaty przyznanej z tytułu dyskryminacji. Brak bogatego orzecznictwa w tym przedmiocie powoduje konieczność odwołania się do ogólnych dyrektyw. Sąd Najwyższy wskazał, że zadośćuczynienie ma realizować trzy podstawowe funkcje: kompensacyjną, represyjną i prewencyjno-wychowawczą ${ }^{55}$. Funkcje zadośćuczynienia stanowią wyraz trzech podstawowych czynników, jakie powinien uwzględnić sąd ustalając wysokość zadośćuczynienia. Po pierwsze, zadośćuczynienie powinno być przyznane w wysokości umożliwiającej pokrzywdzonemu uzyskanie satysfakcji adekwatnej do cierpień i krzywd, jakich doznał, dlatego w pierwszym rzędzie sąd powinien ocenić rozmiar krzywdy. Podstawowym czynnikiem decydującym o rozmiarze krzywdy jest rodzaj naruszonego dobra osobistego ${ }^{56}$. W przypadku dyskryminacji naruszane są różnego rodzaju dobra

52 Postanowienie SN z 18 października 1967 r., sygn. akt II CZ 92/67, OSPiKA 1968, nr 10, poz. 208.

${ }^{53}$ Ustawodawca w art. 24 k.c. wskazał, że w razie naruszenia dóbr osobistych podmiot prawa może żądać zaniechania tego działania, chyba że nie jest ono bezprawne. W razie dokonanego naruszenia może on także żądać, ażeby osoba, która dopuściła się naruszenia, dopełniła czynności potrzebnych do usunięcia jego skutków, w szczególności żeby złożyła oświadczenie odpowiedniej treści i w odpowiedniej formie. Na zasadach przewidzianych w kodeksie może on również żądać zadośćuczynienia pieniężnego lub zapłaty odpowiedniej sumy pieniężnej na wskazany cel społeczny. Natomiast jeżeli wskutek naruszenia dobra osobistego została wyrządzona szkoda majątkowa, poszkodowany może żądać jej naprawienia na zasadach ogólnych.

${ }^{54}$ Zgodnie z art. 448 k.c.: „W razie naruszenia dobra osobistego sąd może przyznać temu, czyje dobro osobiste zostało naruszone, odpowiednią sumę tytułem zadośćuczynienia pieniężnego za doznaną krzywdę lub na jego żądanie zasądzić odpowiednią sumę pieniężną na wskazany przez niego cel społeczny, niezależnie od innych środków potrzebnych do usunięcia skutków naruszenia".

${ }_{55}$ Wyrok SN z 29 września 2004 r, sygn. akt II CK 531/03, Legalis. W uzasadnieniu SN wskazał, że: „Kompensacja krzywdy ma odmienny charakter niż kompensacja szkody majątkowej — polega na wynagrodzeniu cierpień, jakich pokrzywdzony doznał w wyniku czynu niedozwolonego, dlatego wysokość zadośćuczynienia jest w pierwszym rzędzie uwarunkowana intensywnością cierpień i czasem ich trwania. Funkcja represyjna zadośćuczynienia oznacza, że jego wysokość powinna być dla sprawcy szkody adekwatną sankcją do popełnionego czynu i spowodowanej krzywdy. Funkcja prewencyjno-wychowawcza realizowana jest, jeśli wysokość zadośćuczynienia jest proporcjonalna do stopnia potępienia zachowania sprawcy krzywdy w odbiorze społecznym".

${ }^{56}$ Wyrok SA w Łodzi z 14 kwietnia 2010 r., sygn. akt I ACa 178/10, OSA/Ldz. z 2010, nr 3, poz. 24. 
osobiste (godność, dobre imię, cześć, wolność sumienia), dlatego też zasadny jest postulat, aby rekompensata była odpowiednio wysoka. Nie należy jednak pomijać innych kryteriów w postaci adekwatności do stanu majątkowego sprawcy, a także nastawienia sprawcy do czynu, a także rodzaju winy ${ }^{57}$.

Podsumowując - powództwo o naruszenie dóbr osobistych jest najczęściej występujące, bowiem dotyczy wszystkich podmiotów prawa. Roszczeń z tytułu krzywdy będą mogły dochodzić jedynie osoby fizyczne. Zakres przedmiotowy obejmuje natomiast akty dyskryminacji nieobjęte ochroną w prawie pracowniczym, nie budzi jednak wątpliwości, że jednostka może dochodzić rekompensaty doznanej szkody majątkowej oraz krzywdy. Trzeba wskazać, że poszukiwanie ochrony naruszonych dóbr osobistych przez praktyki dyskryminacyjne nie jest dostatecznie rozpoznanym społecznie środkiem. Taki stan rzeczy powoduje, że brakuje rozstrzygnięć sądowych, co uniemożliwia precyzyjne wskazanie sposobu miarkowania dochodzonych roszczeń. W moim przekonaniu przewidziane w kodeksie cywilnym środki ochrony wymagają nie tylko wykazania faktu dyskryminacji, ale przede wszystkim wykazania szkody oraz krzywdy. Jedynie taka forma podejmowanych działań umożliwi wprowadzenie bardziej efektywnej i komplementarnej ochrony zasady równości.

Kolejnym środkiem ochrony przed naruszeniem konstytucyjnego zakazu dyskryminacji jest powództwo uregulowane w kodeksie pracy. Należy podkreślić, że ustawodawca w art. 183a k.p. wprowadza ogólny zakaz dyskryminowania w zatrudnieniu. Zgodnie $\mathrm{z}$ tym artykułem pracownicy powinni być równo traktowani w zakresie nawiązania i rozwiązania stosunku pracy, warunków zatrudnienia, awansowania oraz dostępu do szkolenia w celu podnoszenia kwalifikacji zawodowych, w szczególności bez względu na płeć, wiek, niepełnosprawność, rasę, religię, narodowość, przekonania polityczne, przynależność związkową, pochodzenie etniczne, wyznanie, orientację seksualną, a także bez względu na zatrudnienie na czas określony lub nieokreślony, albo w pełnym lub w niepełnym wymiarze czasu pracy. W judykaturze słusznie podkreśla się, że wskazany katalog cech osobowych jest katalogiem otwartym ${ }^{58}$.

Przykładowe wyliczenie objętych przepisem kryteriów wskazuje, że niewątpliwie chodzi tu o cechy i właściwości osobiste człowieka niezwiązane z wykonywaną pracą i to o tak doniosłym znaczeniu społecznym, że zostały przez ustawodawcę uznane za zakazane kryteria różnicowania w dziedzinie zatrudnienia. Otwarty katalog tych przyczyn pozwala zatem na jego uzupełnienie wyłącznie o inne cechy (właściwości, przymioty) osobiste o społecznie doniosłym znaczeniu, takie jak np. światopogląd, nosicielstwo wirusa HIV, a nawet wygląd, jeżeli w określonych okolicznościach może być uznany za przyczynę różnicowania pracowników stanowiącego przejaw dyskryminacji w postaci molestowania. Przedmiotowy zakaz odnosi się do wszelkich form dyskryminacji (bezpośredniej i pośredniej) ${ }^{59}$. Zakres podmiotowy rzeczonej normy

57 P. Sobolewski, uwagi do art. 23 k.c. ...

58 Wyrok SN z 14 grudnia 2017 r., sygn. akt I PK 343/16, Legalis.

59 Zgodnie $\mathrm{z}$ art. $18^{3 \mathrm{a}} \S 2$ k.p.: „Równe traktowanie w zatrudnieniu oznacza niedyskryminowanie w jakikolwiek sposób, bezpośrednio lub pośrednio, z przyczyn określonych w $\S 1$ ”. 
prawnej obejmuje wszystkich pracowników, a więc osoby zatrudnione na podstawie umowy o pracę, powołania, wyboru, mianowania lub spółdzielczej umowy o pracę (art. 2 k.p.). Nakaz równego traktowania zawarty w art. $18^{3 a}$ k.p. odnosi się do wszystkich etapów stosunku pracy ${ }^{60}$. Osoba dochodząca roszczeń będzie zobowiązana do wskazania przyczyny, ze względu na którą dopuszczono się wobec niej aktu dyskryminacji ${ }^{61}$. Jak słusznie zauważył SN, w kwestii niedyskryminacji w zatrudnieniu, gdy różnicowanie sytuacji pracowników wynika wyłącznie z zastosowania przez pracodawcę niedozwolonego przez ustawę kryterium, co opiera się wprost na założeniu, dyferencjacja praw pracowniczych nie ma w tym przypadku podstawy w odrębnościach związanych z obowiązkami ciążącymi na danych osobach, sposobem ich wypełnienia czy też ich kwalifikacjami ${ }^{62}$. Jest to naturalną konsekwencją faktu, że do naruszenia zasady niedyskryminacji w zatrudnieniu może dojść tylko wtedy, gdy zróżnicowanie sytuacji pracowników wynika wyłącznie z zastosowania przez pracodawcę niedozwolonego przez ustawę kryterium ${ }^{63}$.

W przypadku zaistnienia aktu dyskryminacji pracownik ma prawo dochodzić odszkodowania $\mathrm{w}$ wysokości nie niższej niż minimalne wynagrodzenie za pracę (art. 183d k.p.). Dyskryminacja pracownicza może powodować zarówno szkodę materialną, jak i niematerialną ${ }^{64}$. Szkoda niematerialna wyraża się przez upokorzenie, stres odczuwany przez dyskryminowanego pracownika itd. Jednak poniesienie przez pracownika szkody w określonym rozmiarze będzie stanowiło wskazówkę do ustalenia wysokości tego odszkodowania. W toku postępowania należy wykazać wiele okoliczności. Koniecznymi przesłankami co do zasady będą szkoda (rozumiana jako uszczerbek w dobrach prawnie chronionych osoby poszkodowanej), fakt, z którym ustawa łączy obowiązek odszkodowawczy (naruszenie zasady równego traktowania przez pracodawcę) i adekwatny związek przyczynowy pomiędzy owym faktem a szkodąa ${ }^{65}$. Przy miarkowaniu krzywdy doznanej przez pracownika w związku z dyskryminacją, sąd powinien brać pod uwagę aspekty, które zostały omówione przy dobrach osobistych, a w szczególności doznaną krzywdę, analogicznie stosując przy tym zasady związane z miarkowaniem proporcjonalnej rekompensaty.

Powództwo związane z dyskryminacją pracowniczą będzie miało najmniejszy zakres zastosowania, bowiem podmiotami mogącymi je wystosować będą wyłącznie

${ }^{60}$ Przepis ten obejmuje etap rekrutacji (kiedy w rzeczywistości mamy jeszcze do czynienia z kandydatem na pracownika, czyli potencjalnym pracownikiem), następnie etap kształtowania praw i obowiązków pracownika (czyli etap ustalania rodzaju pracy, wymiaru etatu, wynagrodzenia itd.), aż po etap zwalniania (tutaj szczególnie wrażliwa jest kwestia doboru pracowników do zwolnienia, wybierania podstawy zwolnienia i jego uzasadniania).

${ }^{61}$ Wyrok SN z a 18 września 2008 r., sygn. akt II PK 27/08, „Monitor Prawa Pracy” 2009, nr 3, s. 139.

${ }^{62}$ Wyrok SN z 19 lutego 2008 r., sygn. akt II PK 256/07, OSNP 2009, nr 9-10, poz. 116.

${ }^{63}$ Wyrok SN z 12 września 2006 r., sygn. akt I PK 89/06, „Monitor Prawa Pracy” 2007, nr 2, s. 88.

${ }^{64}$ A. Bolesta, uwagi do art. 183d k.p., [w:] Kodeks pracy. Komentarz, red. K. Walczak, Warszawa 2017.

${ }^{65}$ P. Korus, uwagi do art. 183d k.p., [w:] Kodeks pracy. Komentarz, red. A. Sobczyk, Warszawa 2018. 
pracownicy w rozumieniu kodeksu pracy ${ }^{66}$. Jednak należy zauważyć, że zakres cech osobowościowych objętych ochroną jest szeroki. Ustawodawca, tworząc katalog otwarty cech wrażliwych, zapewnił szeroki zakres ochrony. Również wprowadzenie minimalnej kwoty rekompensaty za dyskryminację jest słusznym rozwiązaniem (w wysokość minimalnego wynagrodzenia za pracę $\mathrm{w}$ danym roku), daje bowiem pracownikowi pewność otrzymania określonej kwoty. Stanowi także punkt wyjścia dla sądów w procesie miarkowania stosownej rekompensaty. Jednak negatywnie należy ocenić wysokość tej rekompensaty, bowiem nie spełnia ona funkcji kompensacyjnej i prewencyjnej.

Powództwo przeciw dyskryminacji jest ostatnim środkiem prawnym, na podstawie którego podmioty prawa mogą poszukiwać ochrony przed dyskryminacją. Prawodawca już w art. 1 ustawy równościowej określa główny cel tego aktu ${ }^{67}$. Jest nim zapobieganie naruszeniom zasady równego traktowania w takich obszarach jak kształcenie zawodowe, podejmowanie i wykonywanie działalności gospodarczej i zawodowej, przystępowanie i działania w związkach i samorządach zawodowych, dostęp do zabezpieczenia społecznego, szkolnictwa wyższego i oświaty, opieki zdrowotnej oraz usług. W ustawie równościowej został ustalony katalog cech uznanych za prawnie chronione i wskazano na płeć, rasę, pochodzenie etniczne, narodowość, religię, wyznanie, światopogląd, niepełnosprawność, wiek lub orientację seksualną. Jest to katalog zamknięty, co różni analizowaną regulację od tej zawartej w kodeksie pracy, w którym ustawodawca pozostawił katalog otwarty, wskazując jedynie przykładowe cechy prawnie chronione. Zamknięcie katalogu cech różnicujących w ustawie równościowej należy ocenić negatywnie, ponieważ jest to kontradyktoryjne do rozwiązań przyjętych w Konstytucji RP, z których wynika, że nikt nie może być dyskryminowany ze względu na jakąkolwiek cechę. Zamknięcie katalogu w ustawie równościowej znacznie ogranicza zakres zastosowania ustawy, zmniejszając przy tym ochronę podmiotów prawa przed dyskryminacją. Wprowadzenie katalogu otwartego umożliwiłoby sądom rozszerzenie zakresu zastosowania ustawy równościowej w przypadkach tego wymagających, zaś obecne rozwiązania mogą prowadzić do ograniczenia ochrony podmiotów dyskryminowanych ze względu na inne cechy. W obecnym staniem prawnym podmioty, do których nie ma zastosowania powództwo przeciw dyskryminacji, korzystają z ochrony dóbr osobistych zagwarantowanych w kodeksie cywilnym. Ustawodawca w art. 4 u.o.r. wskazał na obszary, wobec których ma zastosowanie ustawa ${ }^{68}$.

${ }^{66} \mathrm{~W}$ rozumieniu art. 2 k.p. przymiot pracownika posiada osoba, która związana jest z pracodawcą szczególną więzią prawną nazywaną stosunkiem pracy. Więź ta powstaje w wyniku dokonania jednej z następujących czynności prawnych: zawarcia umowy o pracę, aktu powołania, aktu wyboru, aktu mianowania albo też zawarcia spółdzielczej umowy o pracę.

${ }^{67}$ Art. 1 ustawy równościowej: „Ustawa określa obszary i sposoby przeciwdziałania naruszeniom zasady równego traktowania ze względu na płeć, rasę, pochodzenie etniczne, narodowość, religię, wyznanie, światopogląd, niepełnosprawność, wiek lub orientację seksualną oraz organy właściwe w tym zakresie".

${ }^{68}$ Zgodnie z art. 4 u.o.r. akt ten stosuje się w zakresie: 1) podejmowania kształcenia zawodowego, w tym dokształcania, doskonalenia, przekwalifikowania zawodowego oraz praktyk zawodowych; 2) warunków podejmowania i wykonywania działalności gospodarczej lub zawodowej, w tym w szczególności w ramach stosunku pracy albo pracy na podstawie umowy cywilnoprawnej; 3) przystępowania i działania 
Zakres przedmiotowy wyznacza m.in.: edukacja, warunki podejmowania i wykonywania działalności gospodarczej lub zawodowej, uczestnictwo w związkach zawodowych, dostęp do korzystania z instrumentów rynków pracy i usług rynku pracy. Zgodnie $\mathrm{z}$ art. 3 ustawy równościowej, ustawodawca chroni podmioty dotknięte zarówno dyskryminacją bezpośrednią ${ }^{69}$, jak i jej pośrednimi przejawami ${ }^{70}$. Jak trafnie zauważyła Izabela Florczak, ,[...] ograniczenie katalogu przyczyn mogących stanowić kryteria dyskryminacyjne przy dokonywaniu wyboru strony umowy jest niczym nieuzasadnione i godzi w podstawowe cele regulacji. To właśnie na etapie doboru kontrahenta przejawy dyskryminacji mają najczęściej miejsce i ten etap współpracy między stronami powinien być szczególnie chroniony przy zachowaniu obowiązującej w polskim porządku prawnym zasady autonomii woli, której jednym z aspektów jest swoboda wyboru kontrahenta" ${ }^{\text {"1 }}$.

Środkiem ochrony wprowadzonym przez ustawę równościową jest powództwo przeciw dyskryminacji. Ustawa równościowa przyznaje każdemu, wobec kogo zasada równego traktowania została naruszona, prawo do odszkodowania (art. 13 ust. 1 u.o.r.). $\mathrm{Z}$ kolei art. 14 u.o.r. przewiduje, że ,[k]to zarzuca naruszenie zasady równego traktowania, uprawdopodobnia fakt jej naruszenia” (ust. 2) i „, [w] przypadku uprawdopodobnienia naruszenia zasady równego traktowania ten, któremu zarzucono naruszenie tej

w związkach zawodowych, organizacjach pracodawców oraz samorządach zawodowych, a także korzystania z uprawnień przysługujących członkom tych organizacji; 4) dostępu i warunków korzystania z: a) instrumentów rynku pracy i usług rynku pracy określonych w ustawie z dnia 20 kwietnia $2004 \mathrm{r}$. o promocji zatrudnienia i instytucjach rynku pracy (tekst jedn. Dz.U. 2016 r. poz. 645, 691, 868) oferowanych przez instytucje rynku pracy oraz instrumentów rynku pracy i usług rynku pracy oferowanych przez inne podmioty działające na rzecz zatrudnienia, rozwoju zasobów ludzkich i przeciwdziałania bezrobociu, b) zabezpieczenia społecznego, c) opieki zdrowotnej, d) oświaty i szkolnictwa wyższego, e) usług, w tym usług mieszkaniowych, rzeczy oraz nabywania praw $i$ energii, jeżeli są one oferowane publicznie.

${ }^{69}$ Zgodnie z definicją legalną wskazaną w przepisie art. 3 pkt 1 u.o.r. przez dyskryminację bezpośrednią rozumie się sytuację, w której osoba fizyczna ze względu na płeć, rasę, pochodzenie etniczne, narodowość, religię, wyznanie, światopogląd, niepełnosprawność, wiek lub orientację seksualną jest traktowana mniej korzystnie, niż jest, była lub byłaby traktowana inna osoba w porównywalnej sytuacji.

${ }^{70}$ Zgodnie z definicją legalną wskazaną w przepisie art. 3 pkt 2 u.o.r. rozumie się przez to sytuację, w której dla osoby fizycznej ze względu na płeć, rasę, pochodzenie etniczne, narodowość, religię, wyznanie, światopogląd, niepełnosprawność, wiek lub orientację seksualną na skutek pozornie neutralnego postanowienia, zastosowanego kryterium lub podjętego działania występują lub mogłyby wystąpić niekorzystne dysproporcje lub szczególnie niekorzystna dla niej sytuacja, chyba że postanowienie, kryterium lub działanie jest obiektywnie uzasadnione ze względu na zgodny z prawem cel, który ma być osiągnięty, a środki służące osiągnięciu tego celu są właściwe i konieczne. Obszarem wyłączonym spod regulacji ustawy są, między innymi, sfera życia prywatnego i rodzinnego, treści zawarte w środkach masowego przekazu oraz swoboda wyboru strony umowy o ile nie jest oparta na płci, rasie, pochodzeniu etnicznym lub narodowości. Skrócenie, względem przewidzianego w art. 3 ustawy, katalogu przyczyn dyskryminujących mogących stanowić naruszenie zasady równego traktowania dotyczącego swobody wyboru strony umowy daje asumpt do twierdzenia, że swobody wyboru strony umowy nie ograniczają niewymienione kryteria (religia, wyznanie, światopogląd, niepełnosprawność, orientacja seksualna).

${ }^{71}$ I. Florczak, Równe traktowanie w zatrudnieniu cywilnoprawnym, „Wiedza Prawnicza” 2012, nr 2, s. 37-40. 
zasady, jest obowiązany wykazać, że nie dopuścił się jej naruszenia” (ust. 3). Przepisy te są źródłem normatywnym powództwa przeciw dyskryminacji.

W sprawach o naruszenie zasady równego traktowania stosuje się odpowiednio przepisy ustawy z dnia 17 listopada 1964 r. - Kodeks postępowania cywilnego ${ }^{72}$. Jednak w związku z treścią przepisów ust. 2 i 3 art. 14 u.o.r. należy wskazać, że ograniczone zostaje stosowanie art. 232 zd. 1 k.p.c., zgodnie z którym ,strony są obowiązane wskazywać dowody dla stwierdzenia faktów, z których wywodzą skutki prawne”. Powołane przepisy ustawy równościowej wprowadzają bowiem zasadę tzw. przeniesionego ciężaru dowodu, według której podmiot (powód) jest zobowiązany jedynie do uprawdopodobnienia okoliczności, że zostało naruszone wobec niego prawo do równego traktowania. Pozwany musi natomiast wykazać, że nie dopuścił naruszenia norm ustawowych ${ }^{73}$, na osobie dyskryminowanej spoczywa jedynie ciężar uprawdopodobnienia faktu nierównego traktowania ${ }^{74}$. Skutki procesowe przyjętego rozwiązania zostaną omówione w dalszej części opracowania.

Podmiot, który w sposób należyty uprawdopodobni naruszenie zasady równego traktowania ma, o czym była już mowa, prawo do odszkodowania, którego źródłem normatywnym jest art. 13 ust. 1 u.o.r. Przepis art. 13 ust. 2 u.o.r. stanowi, że ,[...] w sprawach naruszenia zasady równego traktowania stosuje się Kodeks cywilny”. Odesłanie do tej ustawy rodzi konieczność ustalenia wzajemnych relacji między prawem do odszkodowania w ustawie równościowej i w kodeksie cywilnym. W pierwszej kolejności należy podkreślić, że „odszkodowanie” określone w art. 13 u.o.r. odbiega od klasycznej definicji odszkodowania zawartej w przepisie art. 361 k.c., głównie z tego względu, że pojęcie „odszkodowanie” użyte w kodeksie cywilnym nie konsumuje pojęcia „,zadośćuczynienie". W myśl art. 361 k.c. szkoda może występować w dwojakiej postaci: może obejmować straty, które poszkodowany poniósł (damnum emergens) ${ }^{75}$, albo też utratę korzyści, które mógłby osiągnąć, gdyby szkody mu nie wyrządzono (lucrum cessans). W przypadku zaś dyskryminacji osoby pokrzywdzone zwykle doznają szkód o charakterze niemajątkowym, naruszana bowiem jest ich godnośćc ${ }^{76}$. Zdecydowana większość przejawów dyskryminacji stanowi naruszenie godności, która jest dobrem osobistym

${ }^{72}$ Ustawa z dnia 17 listopada 1964 r. — Kodeks postępowania cywilnego (Dz.U. z 2018 r. poz. 1360) [dalej: k.p.c.].

73 Podobne rozwiązanie ustawodawca zastosował w art. $18^{3 \mathrm{~b}}$ k.p.

${ }^{74}$ Należy podkreślić, że uprawdopodobnienie różni się od udowodnienia tym, że możliwe jest stwierdzenie wysokiego prawdopodobieństwa (a nie pewności) zaistnienia przypadku dyskryminacji, jeżeli weźmie się pod uwagę chociażby spójność wersji zdarzeń zaprezentowanych przez powoda.

75 Przez pojęcie damnum emergens rozumie się każde pogorszenie się sytuacji majątkowej poszkodowanego wskutek zmniejszenia się posiadanych aktywów lub też zwiększenia jego pasywów. Zmniejszenie aktywów następuje przez utratę, ubytek lub zniszczenie poszczególnych elementów majątkowych, które dotąd przysługiwały poszkodowanemu.

76 Podobne stanowisko zajął SN w wyroku z 11 kwietnia 2006 r., sygn. akt I PK 169/05, OSNP 2007, nr 7-8, poz. 93, w którym podniósł m.in., że „dyskryminacja jest nieuchronnie związana z naruszeniem godności drugiego człowieka, a poszanowanie tej godności jest nakazem nie tylko prawnym, lecz również moralnym". 
znajdującym się w relacji do sfery osobowości, uzyskującej konkretyzację w poczuciu własnej wartości człowieka oraz uzasadnionym oczekiwaniu szacunku ze strony innych osób ${ }^{77}$. Konieczna jest więc kompensacja nie tylko szkody materialnej, ale przede wszystkim krzywdy ofiar nierównego traktowania ${ }^{78}$. Sąd Najwyższy „odszkodowanie” za dyskryminację traktuje bardziej jako zadośćuczynienie za doznaną krzywdę niż rekompensatę za poniesioną szkodę majątkową ${ }^{79}$. Tym samym należy odwołać się do wykładni pojęcia „zadośćuczynienie”, którego istotą jest rekompensowanie uszczerbku w dobrach osobistych (szkody niemajątkowej) w takim zakresie, w jakim taka rekompensata, ze względu na szczególny charakter tych dóbr, jest możliwa za pomocą świadczeń pieniężnych. Zadośćuczynienie ma na celu kompensatę nie tylko cierpień fizycznych, ale przede wszystkim niekorzystnych następstw zdarzenia w psychice poszkodowanego i ma mu przywrócić równowagę emocjonalną naruszoną przez doznane cierpienia psychiczne.

Należy konstatować, że wysokość rekompensaty powinna być uzależniona od okoliczności danej sprawy i musi mieć charakter proporcjonalny, skuteczny oraz zniechęcający (prewencyjny) ${ }^{80}$. Z perspektywy ustawy równościowej istotny jest charakter prewencyjny, który stanowi novum w stosunku do zadośćuczynienia w rozumieniu prawa cywilnego. Ten aspekt powinien brać pod uwagę sąd rozpoznający sprawę ${ }^{81}$. Przyznawanie pokrzywdzonym podmiotom rekompensaty proporcjonalnej do doznanej krzywdy może przyczynić się do zmniejszenia przejawów zjawisk dyskryminacyjnych w dalszej perspektywie ${ }^{82}$.

Dochodzenie roszczeń na podstawie ustawy równościowej nie wyklucza wszczęcia postepowania związanego z naruszeniem dóbr osobistych (art. 16 ustawy równościowej $)^{83}$. Zasądzenie rekompensaty na podstawie równościowej nie jest reglamentowane zasadą powagi rzeczy osądzonej w przypadku roszczeń związanych z naruszeniem dóbr osobistych. Dlatego też możliwa będzie podwójna kompensacja.

\section{UPRAWDOPODOBNIENIE AKTU DYSKRYMINACJI - SKUTKI PROCESOWE}

Cechą wspólną wcześniej wymienionych środków ochrony jest sposób prowadzenia postępowania dowodowego w procesie kontradyktoryjnym. Dochodzenie roszczeń

$77 \mathrm{~W}$ orzecznictwie jednoznacznie przyjmuje się, że godność zaliczana jest do katalogu dóbr osobistych; vide orzeczenie SN z 24 września 2015 r., sygn. akt V CSK 741/14, Legalis nr 1358761.

${ }^{78}$ Do takiej konstatacji można dojść chociażby na podstawie wyroku SA w Białymstoku z 15 stycznia 2016 r., sygn. akt I Aca 801/15, LEX nr 1971101, w którym podniesiono, że pojęcie czci zawiera w sobie dwa aspekty: zewnętrzny (dobre imię, dobra opinia, dobra sława) oraz wewnętrzny (godność osobista, wyobrażenie o własnej wartości).

79 Wyrok SN z 3 kwietnia 2008 r., sygn. akt II PK 286/07, OSNP 2009, nr 15-16, poz. 202.

${ }^{80}$ Wyrok SN z 7 stycznia 2009 r., sygn. akt III PK 43/08, Lex nr 577695.

${ }^{81}$ Podobne stanowisko zajęła również Rzecznik Praw Obywatelskich w wystąpieniu z dnia $28 \mathrm{~V}$ 2012 r., sygn. RPO-687085-I/12/KW/MW.

${ }^{82}$ Wyrok Trybunału Sprawiedliwości z 17 grudnia 2015 r. w sprawie Maria Auxiliadora Arjona Camacho $v$. Securitas Seguridad Espana SA, nr skargi C-407/14.

${ }^{83}$ Art. 16 ustawy równościowej stanowi, że: Dochodzenie roszczeń na podstawie niniejszej ustawy nie pozbawia prawa do dochodzenia roszczeń na podstawie przepisów innych ustaw. 
związanych z aktem dyskryminacji każdorazowo będzie prowadzone na podstawie przepisów kodeksu postępowania cywilnego. W związku z czym to na osobie wywodzącej skutki prawne spoczywa obowiązek udowodnienia podstaw faktycznych dochodzonych roszczeń (art. 6 k.c.). Restrykcyjne zastosowanie tej zasady znacząco utrudniłoby postępowanie w sprawach dyskryminacyjnych, bowiem niezwykle trudno jest poszkodowanemu udowodnić akt dyskryminacji. Problem ten prawidłowo zidentyfikował ustawodawca, modyfikując ogólną zasadę dowodzenia w ten sposób, że powód jest jedynie zobowiązany do uprawdopodobnienia zaistnienia aktu dyskryminacyjnego. Uprawdopodobnienie jest rozumiane jako środek zastępczy dowodu w znaczeniu ścisłym, a więc niedającym pewności, lecz tylko wiarygodność (prawdopodobieństwo) twierdzenia o jakimś fakcie ${ }^{84}$. Jest to środek zwolniony od ścisłych formalności dowodowych, pozwalający na przyspieszenie postępowania. Uprawdopodobnienie sprowadza się do tego, aby w odformalizowany (w stosunku do regulacji dotyczących postępowania dowodowego) sposób przedstawić takie środki, które (po dokonaniu sądowej oceny) pozwolą na przyjęcie, że okoliczności przytaczane przez stronę dla uzasadnienia swojego stanowiska $\mathrm{z}$ wysokim prawdopodobieństwem miały przebieg zgodny z twierdzeniami strony ${ }^{85}$. Uprawdopodobnienie zaistnienia aktu dyskryminacji przenosi ciężar dowodu na podmiot, który miał dyskryminacji się dopuścić. Kreuje swoiste domniemanie prawne, albowiem pozwany musi udowodnić, że odmienne traktowanie było uzasadnione i dyskryminacja w istocie nie zaistniała. Dlatego też sąd cywilny rozpoznający sprawę o naruszenie zasady równego traktowania powinien dokonać oceny przyczyn, z powodu których podmiot podjął akt uznany za dyskryminujący. Obowiązkiem podmiotu, wobec którego uprawdopodobniono dyskryminację, będzie wykazanie, że podejmując zaskarżone działania, kierował się względami obiektywnymi. Inaczej natomiast prezentuje się materia związana z miarkowaniem wysokości rekompensaty. Wysokość szkody, intensywność doznanej krzywdy oraz adekwatny związek przyczynowy musi być udowodniony przez osobę poszkodowaną. Nie korzysta ona już w tym zakresie z dobrodziejstwa przeniesienia ciężaru dowodowego na pozwanego. Może to być jedną z głównych przyczyn stosunkowo niskich rekompensat przyznawanych z tytułu dyskryminacji. Fakt, że w Polsce dochodzenie roszczeń w związku z dyskryminacją wciąż nie jest zjawiskiem powszechnym, powoduje, że osoby dyskryminowane nie mają świadomości przysługujących im praw, ponadto jeżeli strona już uprawdopodobni akt dyskryminacji, to jednak nie przedstawia dowodów pozwalających na określenie szkody materialnej i krzywdy. W konsekwencji sądy przyznają stosunkowo niskie rekompensaty bądź też oddalają powództwa w całości ${ }^{86}$. Jest to tendencja, która nie sprzyja propagowaniu równości, akceptacji odmienności i indywidulanych poglądów jednostki w społeczeństwie.

${ }^{84}$ Vide wyrok NSA z 24 marca 2017 r., sygn. akt I GSK 544/15, Lex nr 2273628.

${ }^{85}$ Vide wyrok SA w Szczecinie z 22 marca 2017 r., sygn. akt I ACa 830/16, Lex nr 2308680.

${ }^{86}$ Vide wyrok Sądu Rejonowego dla Warszawy-Śródmieścia z 9 lipca 2014 r., sygn. akt VI C 402/13, niepubl.; wyrok SO w Warszawie z 18 listopada 2015 r., sygn. akt V Ca 3611/14, niepubl.; wyrok SA w Warszawie - I Wydział Cywilny z 23 sierpnia 2016 r., sygn. akt I ACa 1522/15, Legalis nr 1546506. 


\section{PODSUMOWANIE}

Koncepcja horyzontalnego wymiaru konstytucyjnych praw i wolności jest adekwatną płaszczyzną analizy art. $32 \mathrm{i}$ art. 33 konstytucji. W doktrynie prawa konstytucyjnego z aprobatą przyjmuje się możliwość zastosowania art. 32 ust. 2 i art. 33 w stosunkach horyzontalnych. Podkreśla się jednak, że stosowanie omawianej koncepcji wymaga indywidualnego podejścia i wyważenia określonych praw i wolności konstytucyjnych. Gotowość do stosowania omawianych norm w stosunkach horyzontalnych przejawią także sądy powszechne, Sąd Najwyższy oraz w pewnym stopniu Trybunał Konstytucyjny. Wydaje się jednak, że zwłaszcza TK nie wykazuje szczególnego zainteresowania omawianą koncepcją. Nie budzi jednak wątpliwości, że jednostka ma pełne prawo do ochrony przed dyskryminacją bez względu na rodzaj stosunku prawnego.

Ustawodawca implementował trzy główne środki prawne pozwalające na dochodzenie ochrony prawnej. Po pierwsze, jest to ochrona dóbr osobistych (art. 23 i 24 k.p.), po drugie, powództwo w związku z dyskryminacją pracowniczą (art. 183d k.p.), po trzecie, powództwo przeciw dyskryminacji (art. 13 ust. 1 u.o.r.). Różnią się one od siebie podmiotowym i przedmiotowym zakresem zastosowania. Najszerszy zakres niewątpliwie będą miały przepisy związane z naruszeniem dóbr osobistych. Ochrona dóbr osobistych jest szczególnie relewantna z powodu stosunkowo wąskiego zakresu ochrony przed dyskryminacją zawartego w ustawie równościowej. Głównie poprzez wprowadzenie zamkniętego katalogu cech osobowościowych podlegających ochronie. Działanie ustawodawcy w tym względzie należy uznać za niewłaściwe i sprzeczne z art. 32 i 33 konstytucji, w których to ustawodawca konstytucyjny wprowadził katalog cech prawnie chronionych. Wydaje się jednak, że najbardziej doniosłym problemem jest miarkowanie rekompensaty z tytułu aktów dyskryminacji. Brak orzecznictwa w tym przedmiocie oraz świadomości społecznej powoduje, że wysokość przyznawanych rekompensat nie wypełnia swoich funkcji, a w szczególności roli kompensacyjnej i prewencyjnej. Dlatego też konieczne są dalsze działania zmierzające propagowanie prawa antydyskryminacyjnego w Polsce zarówno w społeczeństwie, jak i wśród prawników.

BIBLIOGRFIA

PIŚMIENNICTWO

Banaszak B., Konstytucja RP, Komentarz, uwagi do art. 32 Konstytucji, C.H. Beck, Warszawa 2012.

Bolesta A., uwagi do art. 183d k.p., [w:] Kodeks pracy. Komentarz, red. K. Walczak, C.H. Beck, Warszawa 2017.

Bosek L., Borysiak W., uwagi do art. 32 Konstytucji RP, [w:] Konstytucja RP. Komentarz, red. M. Safjan, L. Bosek, t. I, C.H. Beck, Warszawa 2016.

Florczak I., Równe traktowanie w zatrudnieniu cywilnoprawnym, „Wiedza Prawnicza” 2012, $\mathrm{nr} 2$.

Florczak-Wątor M., Horyzontalny wymiar praw konstytucyjnych, Monografie Wydziału Prawa i Administracji UJ, Kraków 2014. 
Garlicki L., Bezpośrednie stosowanie Konstytucji, [w:] Konstytucja RP w praktyce. Konferencja, oprac. Biuro Rzecznika Praw Obywatelskich, Łódź 1999.

Garlicki L., Zubik M., uwagi do art. 32 konstytucji, [w:] Konstytucja Rzeczypospolitej Polskiej. Komentarz, t. I, red. L. Garlicki, M. Zubik, Wydawnictwo Sejmowe, Warszawa 2016.

Garlicki L., Zubik M., uwagi do art. 33 konstytucji, [w:] Konstytucja Rzeczypospolitej Polskiej. Komentarz, t. I, red. L. Garlicki, M. Zubik, Wydawnictwo Sejmowe, Warszawa 2016.

Grzybowski S., Ochrona dóbr osobistych wedtug przepisów ogólnych prawa cywilnego, Wydawnictwo Prawnicze, Warszawa 1957.

Korus P., uwagi do art. 183d k.p., [w:] Kodeks pracy. Komentarz, red. A. Sobczyk, C.H. Beck, Warszawa 2018.

Klein A., Elementy zobowiązaniowego stosunku prawnego, Wrocław 1964, „Państwo i Prawo” 1964, z. 12.

Masternak-Kubiak M., Prawo do równego traktowania, [w:] Prawa i wolności obywatelskie w Konstytucji RP, red. B. Banaszak, A. Preisner, C.H. Beck, Warszawa 2002.

Santera W., Bezpośrednie stosowanie Konstytucji przez Sąd Najwyższy, [w:] Bezpośrednie stosowanie Konstytucji Rzeczypospolitej Polskiej Bezpośrednie stosowanie Konstytucji RP przez Trybunat Konstytucyjny, red. K. Działocha, Wydawnictwo Sejmowe, Warszawa 2005.

Sobolewski P., uwagi do art. 1 k.c, [w:] Kodeks cywilny. Komentarz, t. I, red. K. Osajda, Warszawa 2018.

Sobolewski P., uwagi do art. 23 k.c., [w:] Kodeks cywilny. Komentarz, t. I, red. K. Osajda, Warszawa 2018.

Tuleja P., Stosowanie Konstytucji RP w świetle zasady jej nadrzędności (wybrane problemy), Wolters Kluwer, Kraków 2003.

Winczorek P., Komentarz do Konstytucji Rzeczypospolitej Polskiej, Liber, Warszawa 2008.

Winiarska A., W. Klaus, Dyskryminacja i nierówne traktowanie jako zjawisko społeczno-kulturowe, „Studia BAS” 2011, nr 2.

Włodarczyk C., Wokót prywatyzacji w ochronie zdrowia. Kilka Problemów, Biblioteka Cyfrowa, online, <http://www.problemypolitykispolecznej.pl/images/czasopisma/13-14/13-14 18-41.pdf $>$.

Wronkowska S., Ziembiński Z., Zarys teorii prawa, Ars Boni et Aequi, Poznań 2001. 